\title{
Brazilian Portuguese version of the Patient Competency Rating Scale (PCRS-R-BR): semantic adaptation and validity
}

\author{
Versão em português brasileiro da Patient Competency Rating Scale \\ (PCRS-R-BR): adaptação semântica e validade
}

Nicolle Zimmermann, ${ }^{1}$ Ana Paula Almeida de Pereira, ${ }^{2}$ Rochele Paz Fonseca ${ }^{1}$

\begin{abstract}
This study describes the adaptation of a revised Brazilian version of the Patient Competency Rating Scale (PCRS-R-BR), which focuses on executive, mnemonic, and attention functions. Evidence of content-based and external validity is also reported. The cross-cultural adaptation was conducted in five phases: 1 ) translations and back translations; 2) item analysis by authors; 3 ) classification by experts; 4) revisions and reformulations by authors; 5) pilot study with a sample of patients with mild and moderate/severe traumatic brain injury (TBI). Data were analyzed descriptively, and the PCRS-R-BR scores of groups with mild vs. moderate/severe TBI were compared using the Mann-Whitney test. Patients and their relatives were divided into groups and compared using repeated-measures analysis. The results of the PCRS-R-BR questionnaire for relatives and discrepancy scores of patients with moderate/severe TBI revealed significantly more impairment than that found in the group of patients with mild TBI. There were significant differences between item and total scores of both groups of patients and relatives. Results indicated a high level of item content agreement between experts. This study found initial evidence of PCRS-R-BR content-based and external validity when the questionnaire was applied to patients with mild and moderate/severe TBI and their relatives.
\end{abstract}

Keywords: Patient Competency Rating Scale, scales, validation studies, brain injuries.

\section{Resumo}

O presente artigo teve como objetivo apresentar a adaptação transcultural e evidências de validade externa e de conteúdo da versão brasileira revisada da Patient Competency Rating Scale (PCRS-R-BR), com foco nas funções executivas, mnemônicas e atencionais. A adaptação transcultural incluiu cinco fases: 1) tradução e retrotradução; 2) análise de itens por autores; 3) análise de especialistas; 4) revisões e reformulações dos autores; 5) estudo piloto em pacientes com traumatismo cranioencefálico (TCE) leve e moderado/grave. Os dados foram analisados descritivamente e os pacientes com TCE leve e moderado/grave foram comparados nos escores da PCRS-R-BR pelo teste Mann-Whitney. Os pacientes e familiares foram comparados por grupo através da análise de medidas repetidas. Os pacientes com TCE moderado/grave tiveram maior prejuízo que os pacientes com TCE leve no formulário da PCRS-R-BR dos familiares e no escore de discrepância entre pacientes e familiares. Os resultados indicam bons e altos níveis de concordância entre especialistas frente aos componentes avaliados pelos itens. Esse estudo apresentou evidências iniciais de validade de conteúdo da PCRS-R-BR para pacientes com TCE leve e moderado/severo e seus familiares.

Descritores: Patient Competency Rating Scale, escalas, estudos de validade, lesões cerebrais.

\footnotetext{
${ }^{1}$ School of Psychology, Graduate Program in Psychology (Human Cognition), Clinical and Experimental Neuropsychology Research Group, Pontifícia Universidade Católica do Rio Grande do Sul (PUCRS), Porto Alegre, RS, Brazil. Epilepsy Center, Instituto Estadual do Cérebro Paulo Niemeyer, Rio de Janeiro, RJ, Brazil. ${ }^{2}$ Human Sciences, Languages, and Arts, Department of Psychology, Universidade Federal do Paraná (UFPR), Curitiba, PR, Brazil.

Financial support: Conselho Nacional de Desenvolvimento Científico e Tecnológico

Submitted May 09 2013, accepted for publication Nov 26 2013. No conflicts of interest declared concerning the publication of this article.

Suggested citation: Zimmermann N, Pereira APA, Fonseca RP. Brazilian Portuguese version of the Patient Competency Rating Scale (PCRS-R-BR): semantic adaptation and validity. Trends Psychiatry Psychother. 2014;36(1):40-51. http://dx.doi.org/10.1590/2237-6089-2013-0021
} 


\section{Introduction}

The main goal of neuropsychological assessment is to identify the cognitive and behavioral strengths and weaknesses of individuals and to characterize their neurocognitive functioning profile of dissociations and associations. ${ }^{1,2}$ Classical performance measurement methods are the most frequently used in clinical and research settings. However, the applicability of neuropsychological assessments has moved beyond populations with acquired brain injuries, which has raised concerns about the ecological validity of assessment data. 3,4 Scales and questionnaires that investigate cognition improve the ecological and functional validity of test performance data. ${ }^{5}$ Moreover, these tools may also contribute to the investigation of anosognosia, a clinical condition defined by impaired self-awareness. ${ }^{6}$

Anosognosia has been diagnosed in different clinical populations, such as patients with traumatic brain injury (TBI), Alzheimer's disease, schizophrenia, and Huntington's disease. The presence of anosognosia has important implications for interventions in neuropsychology. ${ }^{7}$ During assessment, the evaluation of impaired self-awareness is especially relevant because of its impact on complaint self-report, which may also affect the decision to seek neuropsychological care. In some cases, adherence to rehabilitation may be affected due to lack of patient self-awareness, which may change the outcome after rehabilitation as well. ${ }^{8,9}$ For those reasons, the investigation of this metacognitive function is relevant for clinical and research purposes.

Deaton, ${ }^{10}$ defined three methods of self-awareness assessment: 1) discrepancy between patient's and relative's self-reported scores; 2) discrepancy between patient's and clinician's self-reported scores; 3) discrepancy between patient's self-report and his/her performance on cognitive tasks. A number of instruments have been developed to assess self-awareness, such as questionnaires, scales, and interviews. The SelfAwareness of Deficits Interview (SADI) ${ }^{11}$ investigates quantitative and qualitative aspects of self-awareness, such as functional implications of deficits and the ability to set realistic goals. A study found that SADI had a better correlation with executive function (EF) tests than the Dysexecutive Questionnaire, for example, and demonstrated that it was a predictor of severity in a sample of patients with TBI. ${ }^{12}$ The Awareness Questionnaire (AQ), ${ }^{13}$ another similar instrument, assesses how well patients perform some activities when compared with their pre-injury performance. After 1 year, AQ score was predicted by the time taken to follow commands in a group of people with acute TBI. ${ }^{14}$ The same study also used the Patient Competency Rating Scale (PCRS) $)^{15}$ and found similar results, but PCRS scores seemed to improve over time, whereas AQ scores did not, which may indicate that different things are measured by these two instruments.

The PCRS is one of the most frequently used instruments worldwide to assess self-awareness impairment in patients with TBI. ${ }^{16}$ The original version comprises 30 items that assess emotion, activities of daily living (ADL), cognition and interpersonal relationships. In addition, the PCRS has been adapted for use in rehabilitation centers (PCRS-NR), ${ }^{17}$ and its validity for use with stroke patients has been demonstrated. ${ }^{18}$ In addition, the PCRS has been adapted and validated for use in different cultures. ${ }^{19,20}$ Some studies have found a correlation with measures of EFs in samples of patients with $\mathrm{TBI}^{21}$ and with specific (medial and right dorsal) regions of the prefrontal cortex. ${ }^{22}$ Such data are indicative of what underlies self-awareness assessed by the PCRS.

Despite the relevance of self-awareness assessment, no tools are available for that in Brazil. A Brazilian study has used the Questionário de Demência (Dementia Questionnaire) ${ }^{23}$ to measure cognitive self-awareness in patients with Alzheimer's disease. However, there are no appropriate adaptations and validity publications as far as we know, and no studies about self-awareness measures for neurological samples in Brazil have been published. Given the wellknown cultural and linguistic bias involved in using non-adapted instruments, ${ }^{24}$ the demand in this area has not been met. Valentini et al. ${ }^{25}$ adapted the Harter self-perception profile for children, which assesses competencies in different aspects of life. However, as far as we know, no scales to assess the self-awareness of patients with neurological diseases have been adapted for use in Brazil. In addition, Brazilian centers of neuropsychology are under great pressure due to the high number of patients and lack of time, which is further complicated by the time necessary to apply assessment tools. Those two reasons led us to develop a project to adapt a self-awareness questionnaire transculturally and semantically and produce a tool that does not take long to apply and that has high clinical relevance and applicability. Our review of the literature and our clinical experience identified the three main cognitive demands of patients with TBI: $\mathrm{EFs},{ }^{26}$ memory, ${ }^{27}$ and attention. ${ }^{28}$

Therefore, our study describes the transcultural adaptation and the analysis of content-based validity of the PCRS for patients with EF, memory, and attention deficits. In addition, evidence is reported of the external validity of the PCRS-R-BR in a sample of patients with TBI and their relatives. 


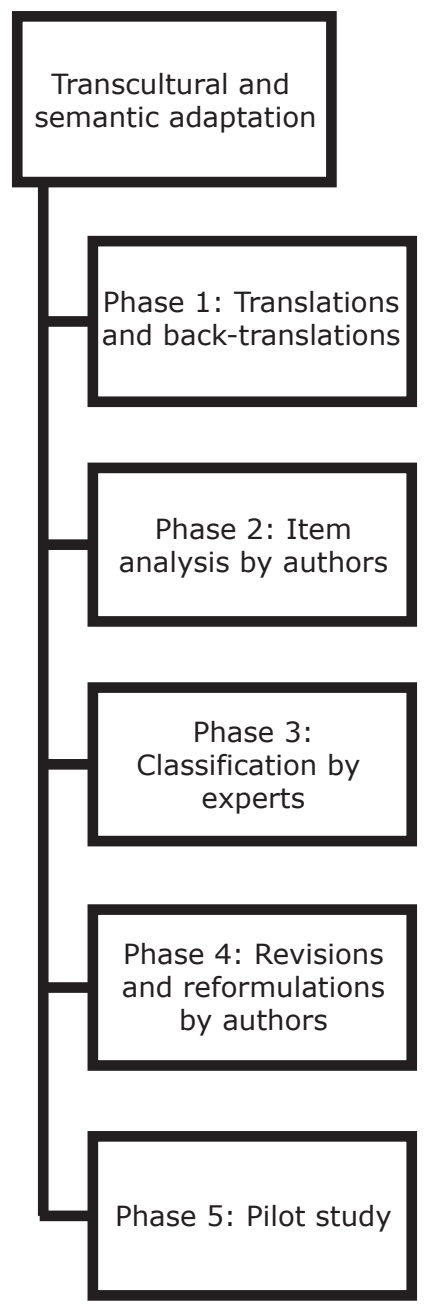

Figure 1 - Flowchart of adaptation phases

\section{Method}

The adaptation of the PCRS and the analysis of its content-based validity was conducted in five phases, shown in Figure 1. Agreement rates for content validity and classification by experts were based on the method described by Andrés \& Marzo. ${ }^{29}$ The original author of the PCRS was contacted and authorized adaptation.

\section{Participants}

This study included 75 adults. Table 1 shows the characteristics of participants in each study phase. The clinical sample in the pilot study is described in detail below.

\section{Description of pilot sample}

The pilot sample comprised 62 adults (age range: 18 to 72 years) with mild $(41.9 \%)$ or moderate/severe $(58.1 \%)$ TBI. Participants were recruited by convenience sampling using contacts collected from medical records of hospitals in Porto Alegre, Brazil. This study was approved by the Ethics Committee of Pontifícia Universidade Católica do Rio Grande do Sul (PUCRS), Brazil (no. 10/05134).

Severity of trauma was classified according to the Glasgow Coma Scale (GCS) score at hospital admission, self-report of loss of consciousness ( $<30$ minutes $=$ mild; 30 minutes to 1 day = moderate; $>1$ day = severe) or posttraumatic amnesia $(<24$ hours $=$ mild; $1-7$ days $=$ moderate $;>7$ days $=$ severe $).{ }^{30}$ Some patients presented with psychiatric symptoms (56.4\%), defined according to self-report or the Structured Clinical Interview for DSMIV Axis I Disorders (SCID-I). ${ }^{31,32}$ However, patients with mild or moderate/severe TBI did not differ in presence of psychiatric symptoms $(p=0.568)$. Sociodemographic and clinical data are shown in Table 1.

\section{Procedures and instruments}

The method used in this study was based on the procedure described by Fonseca et al. ${ }^{33}$ for the adaptation of verbal neuropsychological tests. Neuropsycholinguistic and psychometric factors were analyzed in three steps: translation, analysis by experts and pilot study. These steps evaluate the equivalence of cross-cultural adaptations, as suggested by Reichenheim et al., ${ }^{34}$ as well as the translation and back-translation processes detailed in Gjersing et al. ${ }^{35}$

\section{Translations and back-translations}

The questions were translated independently by two independent translators, generating two translated versions. After that, the two translations were back-translated by other translators, also working independently. These two back-translated versions were analyzed and compared with the original version. The purpose of these two steps was to ensure the semantic equivalence of items and to define the best form to express their meaning.

\section{Item analysis by authors}

The initial purpose of this adaptation of the PCRS was to include only EF, memory, and attention items. Therefore, the cognitive constructs of the 30 original PCRS items were analyzed and classified by doubleblinded experts. The agreement index was calculated according to what was expected for each item and using the expert experiences of one of the authors as the criterion standard.

Complementary changes and inclusions were made during this phase. The version of the PCRS-R-BR to be used with relatives had the same scale questions using the third person. The original PCRS can be accessed in http://www.tbims.org/combi/pcrs/index.html. 
Table 1 - Description of participants in each phase

\begin{tabular}{|c|c|c|c|c|c|c|c|}
\hline Phase & Participants & \multicolumn{6}{|l|}{ Characterization } \\
\hline $\begin{array}{l}\text { (1) Translations and } \\
\text { back-translations }\end{array}$ & $\begin{array}{l}\text { Step } 1 \text { - translation: } \\
\mathrm{n}=2 \text { interpreters }\end{array}$ & \multicolumn{6}{|c|}{$\begin{array}{l}\text { Step } 1 \text { - translation interpreters: } \\
\text { - PhD, neuropsychology professor } \\
\text { - Master's candidate in neuropsychology }\end{array}$} \\
\hline & $\begin{array}{l}\text { Step } 2 \text { - back-translation: } \\
\mathrm{n}=2 \text { interpreters }\end{array}$ & \multicolumn{6}{|c|}{$\begin{array}{l}\text { Step } 2 \text { - back-translation interpreters: } \\
\text { Both bilinguals with long-term life experience in English-speaking } \\
\text { countries } \\
\text { - PhD, neuropsycholinguistics professor } \\
\text { - PhD candidate in neuropsychology }\end{array}$} \\
\hline (2) Item analysis by authors & $\mathrm{n}=3$ neuropsychologists & \multicolumn{6}{|c|}{$\begin{array}{l}\text { - } 2 \mathrm{PhD} \text {, neuropsychology professors } \\
\text { - Master's candidate in neuropsychology }\end{array}$} \\
\hline (3) Analysis by experts & $\mathrm{n}=8$ experts & \multicolumn{6}{|c|}{$\begin{array}{l}\text { Graduated neuropsychology experts }(n=6) \\
\text { Undergraduate psychology experts }(n=2)\end{array}$} \\
\hline $\begin{array}{l}\text { (4) Revisions and } \\
\text { reformulations by authors }\end{array}$ & $\mathrm{n}=3$ neuropsychologists & \multicolumn{6}{|c|}{$\begin{array}{l}\text { - } 2 \text { PhD, neuropsychology professors } \\
\text { - Master's candidate in neuropsychology }\end{array}$} \\
\hline \multirow[t]{9}{*}{ (5) Pilot study } & $\mathrm{n}=62$ patients with TBI & \multicolumn{6}{|c|}{ Mild $(41.9 \%) ;$ moderate/severe $(58.1 \%)$} \\
\hline & & \multirow{2}{*}{ Variables } & \multicolumn{2}{|l|}{ Mild } & \multicolumn{2}{|c|}{$\begin{array}{l}\text { Moderate/ } \\
\text { severe }\end{array}$} & \multirow{2}{*}{ p* } \\
\hline & & & Mean & SD & Mean & SD & \\
\hline & & Age (years) & 38.38 & 13.42 & 35.39 & 14.88 & 0.321 \\
\hline & & Education (years) & 9.54 & 4.06 & 9.11 & 3.44 & 0.477 \\
\hline & & $\begin{array}{l}\text { Socioeconomic } \\
\text { status }^{+}\end{array}$ & 23.12 & 6.29 & 21.22 & 5.54 & 0.184 \\
\hline & & $\begin{array}{l}\text { Frequency of } \\
\text { reading and } \\
\text { writing habits }\end{array}$ & 10.58 & 5.74 & 8.83 & 5.86 & 0.179 \\
\hline & & $\begin{array}{l}\text { Time post-onset } \\
\text { (months) }\end{array}$ & 17.30 & 17.43 & 25.58 & 25.54 & 0.134 \\
\hline & & MMSE score & 26.23 & 3.08 & 24.47 & 3.40 & 0.045 \\
\hline
\end{tabular}

MMSE = Mini Mental State Examination; SD = standard deviation; TBI = traumatic brain injury.

The authors are the same in all study phases.

$* \mathrm{p} \leq 0.05$.

+ Associação Brasileira de Empresas de Pesquisa (2008). http://www.abep.org/novo/Content.aspx?ContentID=301

\section{Classification by experts}

During this phase, cognitive constructs were evaluated, and the items were classified to confirm that they were clearly understood. Each expert made these classifications independently.

\section{Revisions and reformulations by authors}

The authors analyzed the suggestions made by the group for the final changes of different items for the pilot study. Suggestions were read, discussed and voted by the three authors.

\section{Pilot study}

The PCRS-R-BR was applied individually to patients with TBI. The items were read aloud by the examiner, and a printed form was handed out for the participants to read if necessary. No additional explanations were given to participants about the meaning of the questions to avoid differences in item interpretation. However, questions were read as many times as necessary for participants to process and understand them. Participants with clinical signs of poor language comprehension and use were not included in the study. Also, based on our clinical experience with neurological patients, we decided to use the PCRSR-BR as a part of a clinical interview and not as a selfadministered scale. Clinical conditions, such as difficulties in visual sensorial processing, low educational level, low processing speed, and visual attention impairments (unintentionally skipped questions), were recorded.

The Mann-Whitney test for non-parametric data was used to analyze whether the PCRS-R-BR differentiates self-awareness between patients with mild and moderate/ severe TBI. The level of significance was set at $p \leq 0.05$. Total scores of the versions applied to patients and their relatives, as well as discrepancy scores (patients' total score minus relatives' total score) were compared between the groups of patients with TBI. Moreover, repeated-measures analysis was used to compare scores within patient groups and the scores of relatives in each group of patients with TBI to evaluate whether the scores of patients and relatives were discrepant. 
Table 2 - Translations and back-translations

\begin{tabular}{|c|c|c|c|c|c|}
\hline Original question & Translation 2 & Translation 1 & Back-translation 1 & Back-translation 2 & Final version \\
\hline $\begin{array}{l}\text { How much of a } \\
\text { problem do I have } \\
\text { in remembering } \\
\text { names of people I } \\
\text { see often? }\end{array}$ & $\begin{array}{l}\text { Quanta dificuldade } \\
\text { tenho em lembrar } \\
\text { nomes de pessoas } \\
\text { que encontro } \\
\text { frequentemente? }\end{array}$ & $\begin{array}{l}\text { Quanta dificuldade } \\
\text { eu tenho em } \\
\text { lembrar o nome das } \\
\text { pessoas que eu vejo } \\
\text { frequentemente? }\end{array}$ & $\begin{array}{l}\text { How hard is it for } \\
\text { me to remember the } \\
\text { name of people who } \\
\text { I frequently see? }\end{array}$ & $\begin{array}{l}\text { How much difficulty } \\
\text { do I have in } \\
\text { remembering the } \\
\text { names of people I } \\
\text { see often? }\end{array}$ & $\begin{array}{l}\text { Quanta dificuldade } \\
\text { você tem em se } \\
\text { lembrar do nome } \\
\text { das pessoas } \\
\text { que você vê } \\
\text { frequentemente? }\end{array}$ \\
\hline $\begin{array}{l}\text { How much of a } \\
\text { problem do I have } \\
\text { in remembering my } \\
\text { daily schedule? }\end{array}$ & $\begin{array}{l}\text { Quanta dificuldade } \\
\text { tenho em lembrar } \\
\text { meus compromissos } \\
\text { do dia? }\end{array}$ & $\begin{array}{l}\text { Quanta dificuldade } \\
\text { eu tenho em } \\
\text { me lembrar dos } \\
\text { meus horários e } \\
\text { compromissos do } \\
\text { dia? }\end{array}$ & $\begin{array}{l}\text { How hard is it for } \\
\text { me to remember } \\
\text { my schedules and } \\
\text { appointments of the } \\
\text { day? }\end{array}$ & $\begin{array}{l}\text { How much difficulty } \\
\text { do I have to } \\
\text { remember my } \\
\text { schedule and } \\
\text { appointments for the } \\
\text { day? }\end{array}$ & $\begin{array}{l}\text { Quanta dificuldade } \\
\text { você tem em } \\
\text { se lembrar dos } \\
\text { seus horários e } \\
\text { compromissos do } \\
\text { dia? }\end{array}$ \\
\hline $\begin{array}{l}\text { How much of a } \\
\text { problem do I have } \\
\text { in recognizing when } \\
\text { something I say } \\
\text { or do has upset } \\
\text { someone else? }\end{array}$ & $\begin{array}{l}\text { Quanta dificuldade } \\
\text { tenho em perceber } \\
\text { que algo que disse } \\
\text { ou fiz chateou outra } \\
\text { pessoa? }\end{array}$ & $\begin{array}{l}\text { Quanta dificuldade } \\
\text { eu tenho em } \\
\text { reconhecer quando } \\
\text { alguma coisa que } \\
\text { eu digo ou faço } \\
\text { deixa alguém } \\
\text { chateado? }\end{array}$ & $\begin{array}{l}\text { How hard is it for } \\
\text { me to notice that } \\
\text { something I say or } \\
\text { do annoys someone? }\end{array}$ & $\begin{array}{l}\text { How much difficulty } \\
\text { I have in recognizing } \\
\text { when something I } \\
\text { say or do makes } \\
\text { someone upset? }\end{array}$ & $\begin{array}{l}\text { Quanta dificuldade } \\
\text { você tem em } \\
\text { perceber que algo } \\
\text { que disse ou fez } \\
\text { chateou outra } \\
\text { pessoa? }\end{array}$ \\
\hline
\end{tabular}

\section{Results}

\section{Translations and back-translations}

Table 2 shows examples of translated and backtranslated items. Most items did not have any notable differences; however, some terms were different, as in the case of "recognizing" and "notice" on backtranslation. At this point, the translated versions were analyzed, and the authors chose the better Brazilian Portuguese word (semantically and culturally) while reading it in English language context. Note that in the column "final version", the authors decided to rewrite the questions using the second person, instead of the first person, during the phase of Item analysis by authors, as described in the methods section.

\section{Item analysis by authors}

The selection of EF items and memory constructs by the authors is shown in Table 3. Final cognitive construct consensus was reached according to the contribution made by the third expert.

Table 4 shows that about $53 \%$ of the items had $75 \%$ or greater agreement among the experts in the classification of cognitive constructs. Sixteen were included; the following items of the original version were excluded: 2,3 , $4,5,13,14,18,19,21,22,27,28,29$, and 30. Question 13 assessed memory, but it was excluded because the structure and content were unspecific. Question 14 was also excluded because it asked about driving. Although driving requires many EFs, experts agree that most patients with brain injury are advised not to drive for medical reasons, and, therefore, this question might not be applicable to most patients.

As suggested by the first classification made by experts, EF, memory and attention were the cognitive constructs analyzed by the group of experts. Table 3 shows the expert classification of cognitive constructs for each item made.

\section{Revisions and reformulations made by the authors}

After analyzing the suggestions made by the experts, the authors either approved changes or not. They decided to include one more question for focused attention only. Additionally, an extra option, "not applicable" (translated to Brazilian Portuguese as não se aplica), was included for activities or responsibilities that patients do not have. The answers were scored 1 to 5 , and both the options "can do with ease" and "not applicable" were scored 5 . Table 4 shows the changes suggested by the neuropsychology experts for the first version of items. Appendices 1 and 2 show the final versions of the PCRSR-BR for patients and relatives.

\section{Pilot study}

Results revealed that there were no significant differences between the groups of patients with mild (mean $[\mathrm{M}]=65.31$; standard deviation $[\mathrm{SD}]=9.51)$ and moderate/severe $(M=66.36 ; S D=11.45)$ TBI $(p$ $=0.553)$. However, the total score for relatives was significantly different ( $p=0.007)$, and the group with mild TBI ( $M=71.31 ; S D=14.58)$ had higher scores than the group with moderate/severe TBI $(M=59.81$; $\mathrm{SD}=$ 19.06). Finally, the discrepancy score was also different between groups $(p=0.020)$ (mild TBI $M=-5.54$; SD $=14.73 ;$ moderate/severe $M=5.47 ; S D=20.36)$. The results of the comparison of PCRS-R-BR item and total scores within the groups of patients and their relatives 
Table 3 - Cognitive constructs of the original Patient Competency Rating Scale as classified by experts

\begin{tabular}{|c|c|c|c|c|}
\hline Items/experts & Specialist 1 & Specialist 2 & Specialist 3 & Agreement rate $(\%)$ \\
\hline 1 & $\mathrm{EF}$ & $A D L$ & $\mathrm{EF}$ & 66.6 \\
\hline 2 & $A D L$ & $A D L$ & $A D L$ & 100 \\
\hline 3 & $A D L$ & $A D L, E F$ & $A D L$ & 100 \\
\hline 4 & $A D L$ & $A D L$ & $A D L$ & 100 \\
\hline 5 & $A D L$ & $A D L$ & $A D L$ & 100 \\
\hline 6 & $\mathrm{EF}$ & $\mathrm{EF}$ & $\mathrm{EF}$ & 100 \\
\hline 7 & $\mathrm{EF}$ & EF, MEM & $\mathrm{EF}$ & 100 \\
\hline 8 & $\mathrm{EF}$ & $\mathrm{EF}$ & $\mathrm{EF}$ & 100 \\
\hline 9 & $\mathrm{EF}$ & $\mathrm{EF}$ & $\mathrm{EF}$ & 100 \\
\hline 10 & EP-MEM & EP-MEM & EP-MEM & 100 \\
\hline 11 & SEM-MEM & SEM-MEM & SEM-MEM & 100 \\
\hline 12 & PROSP-MEM & PROSP-MEM & PROSP-MEM & 100 \\
\hline 13 & MEM & MEM & MEM & 100 \\
\hline 14 & $A D L$ & EF, praxis & $\mathrm{EF}$, praxis & 66.6 \\
\hline 15 & $\mathrm{EF}$ & $\mathrm{EF}$ & $\mathrm{EF}$ & 100 \\
\hline 16 & $\mathrm{EF}$ & $\mathrm{EF}$ & $\mathrm{EF}$ & 100 \\
\hline 17 & $\mathrm{EF}$ & $\mathrm{EF}$ & $\mathrm{EF}$ & 100 \\
\hline 18 & Emotions & Emotions & Emotions & 100 \\
\hline 19 & Emotions & Emotions & Emotions & 100 \\
\hline 20 & $\mathrm{EF}$ & $\mathrm{EF}$ & $\mathrm{EF}$ & 100 \\
\hline 21 & Emotions & Emotions & Emotions & 100 \\
\hline 22 & $\mathrm{EF}$ & Emotions & Emotions & 100 \\
\hline 23 & EF, TOM & EF, TOM & EF, TOM & 100 \\
\hline 24 & $\mathrm{EF}$ & $\mathrm{EF}$ & $\mathrm{EF}$ & 100 \\
\hline 25 & $\mathrm{EF}$ & $\begin{array}{l}\text { Language } \\
\text { comprehension }\end{array}$ & $\mathrm{EF}$ & 66.6 \\
\hline 26 & $\mathrm{EF}$ & EF, PROSP-MEM & $\mathrm{EF}$ & 100 \\
\hline 27 & Emotions & Emotions & Emotions & 100 \\
\hline 28 & Emotions & Emotions & Emotions & 100 \\
\hline 29 & Emotions & Emotions & Emotions & 100 \\
\hline 30 & Emotions & Emotions & Emotions & 100 \\
\hline
\end{tabular}

$\mathrm{ADL}=$ activity of daily living; $\mathrm{EF}=$ executive functions; $\mathrm{EP}=$ episodic; $\mathrm{MEM}=$ memory; $\mathrm{PROSP}=$ prospective; $\mathrm{SEM}=$ semantic; $\mathrm{TOM}=$ theory of mind.

are shown in Table 5. There were significant differences within groups, and the group with moderate/severe TBI had differences in more items than the group with mild TBI, but the differences were not statistically significant.

\section{Discussion}

This study described the process of PCRS adaptation to Brazilian reality, culture and language. Moreover, it used descriptive and statistical analysis to evaluate the instrument's content-based and external validity. The PCRS-R-BR adaptation and validation process could not be directly compared with previous published versions of the PCRS because the scale's content and number of items have been changed. Therefore, our findings will be discussed in terms of general expectations in each phase of the process, as well as of expectations for a self-awareness assessment instrument. 
Table 4 - Classification of cognitive components by experts

\begin{tabular}{lll}
\hline Question & Cognitive components & \% \\
\hline 1 & Planning & 75 \\
2 & Planning & 62.5 \\
3 & Planning & 87.5 \\
4 & Initiation & 100 \\
5 & Focused attention & 62.5 \\
6 & Episodic memory & 75 \\
7 & Episodic-semantic memory & 87.5 \\
8 & Prospective memory & 62.5 \\
9 & Flexibility & 50 \\
10 & Flexibility & 100 \\
11 & Flexibility & 37.2 \\
12 & Inhibition & 62.5 \\
13 & Self-monitoring & 50 \\
14 & Planning & 75 \\
15 & Flexibility & 50 \\
16 & Planning & 62.5 \\
\hline
\end{tabular}

Examples of item changes according to suggestions made by experts

\begin{tabular}{ll}
\hline Initial version & Final version \\
\hline $\begin{array}{l}\text { Quanta dificuldade eu tenho em pedir ajuda } \\
\text { quando estou confuso(a)? }\end{array}$ & $\begin{array}{l}\text { Quanta dificuldade você tem em pedir ajuda quando está confuso(a) para resolver } \\
\text { um problema ou quando não entende alguma coisa? }\end{array}$ \\
$\begin{array}{l}\text { Quanta dificuldade eu tenho em agir de modo } \\
\text { esperado quando estou entre amigos? }\end{array}$ & $\begin{array}{l}\text { Quanta dificuldade você tem em agir de modo esperado quando está entre } \\
\text { amigos? Por exemplo, cuidando para não fazer coisas que as pessoas não gostam. }\end{array}$ \\
$\begin{array}{l}\text { Quanta dificuldade eu tenho em manter-me } \\
\text { envolvido nas atividades de trabalho mesmo } \\
\text { quando estou me sentindo entediado(a) ou } \\
\text { cansado(a)? }\end{array}$ & $\begin{array}{l}\text { Quanta dificuldade você tem em se manter envolvido em atividades obrigatórias } \\
\text { que tem que terminar mesmo quando está se sentindo cansado ou entediado? }\end{array}$ \\
\end{tabular}

\section{Translations and back-translations}

The translations and back-translations raised especially important issues regarding the main structure of sentences and questions, because some structures used in English, such as "how much of a problem," do not exist in Brazilian Portuguese and cannot be literally translated. Moreover, some divergent expressions were used, and some had similar meanings, which was discussed and clarified during the phase of analysis by experts.

\section{Item classification by experts}

This phase was important for the selection of the main items of EF, memory and attention, one of the main purposes of this adaptation. Results revealed a high level of agreement between experts. The items for which there was no agreement between experts were the ones in which the activity or ability demanded many functions, or at least two equally important functions, such as in item 11 of the PCRS-R-BR. This phenomenon was expected because different cognitive functions are related, and in the real world functions are not used separately by individuals, particularly not in the case of EF.

In addition, in this phase the questions were rewritten in the second person, instead of in the first person, to address the difficulties that the patients had in attention, language comprehension, and processing speed. Similar impairments have been described in other studies about TBI. To our knowledge, this is the first scale in which the questionnaire was adapted to obtain more accurate results from patients with TBI. Moreover, the authors included an item (number 17) that assesses sustained attention, because the original PCRS items did not have questions about attention alone. The authors also included the "not applicable" option. This inclusion was essential because some patients did not do some activities, or had never experienced some situations.

\section{Classification by experts and revisions and reformulations by authors}

The content-based analysis used to validate the PCRS-R-BR revealed high rates of agreement between 
Brazilian Portuguese version of PCRS-R-BR - Zimmermann et al.

Table 5 - Comparative analysis of item and total scores within groups of patients and their significant others

\begin{tabular}{|c|c|c|c|c|c|c|c|c|c|c|c|c|}
\hline \multirow[b]{3}{*}{ Items } & \multicolumn{6}{|c|}{ Mild } & \multicolumn{6}{|c|}{ Moderate/severe } \\
\hline & \multicolumn{2}{|c|}{ Patient } & \multicolumn{2}{|c|}{ Significant other } & \multirow[b]{2}{*}{$\mathbf{F}$} & \multirow[b]{2}{*}{$\mathbf{p}$} & \multicolumn{2}{|c|}{ Patient } & \multicolumn{2}{|c|}{ Significant other } & \multirow[b]{2}{*}{$\mathbf{F}$} & \multirow[b]{2}{*}{$\mathbf{p}$} \\
\hline & $\mathbf{M}$ & SD & $\mathbf{M}$ & SD & & & $\mathbf{M}$ & SD & $\mathbf{M}$ & SD & & \\
\hline 1 & 4.54 & 0.99 & 4.62 & 0.80 & 0.15 & 0.703 & 4.33 & 0.96 & 3.75 & 1.42 & 5.31 & $0.027 *$ \\
\hline 2 & 3.38 & 1.20 & 4.04 & 1.22 & 4.97 & $0.035^{*}$ & 3.78 & 1.15 & 3.14 & 1.44 & 4.01 & $0.053 *$ \\
\hline 3 & 3.92 & 1.06 & 4.19 & 1.17 & 1.20 & 0.283 & 4.39 & 0.96 & 3.78 & 1.42 & 6.31 & $0.017 *$ \\
\hline 4 & 3.73 & 1.34 & 4.35 & 1.13 & 4.23 & $0.050 *$ & 3.69 & 1.31 & 3.81 & 1.14 & 0.21 & 0.648 \\
\hline 5 & 3.42 & 1.06 & 4.08 & 1.35 & 3.24 & 0.084 & 3.50 & 1.28 & 3.42 & 1.59 & 0.08 & 0.782 \\
\hline 6 & 3.73 & 1.00 & 4.23 & 1.18 & 4.22 & $0.051 *$ & 3.67 & 1.22 & 3.22 & 1.48 & 2.52 & 0.122 \\
\hline 7 & 4.46 & 0.76 & 4.62 & 0.64 & 0.61 & 0.444 & 3.86 & 1.22 & 4.22 & 0.99 & 4.08 & $0.051^{*}$ \\
\hline 8 & 3.88 & 1.14 & 4.08 & 1.41 & 0.35 & 0.558 & 3.75 & 1.50 & 3.58 & 1.36 & 0.29 & 0.594 \\
\hline 9 & 3.38 & 1.33 & 3.96 & 1.34 & 3.17 & 0.087 & 3.97 & 1.18 & 3.83 & 1.28 & 0.30 & 0.586 \\
\hline 10 & 3.54 & 1.21 & 3.58 & 1.30 & 0.02 & 0.903 & 3.53 & 1.34 & 3.47 & 1.28 & 0.03 & 0.859 \\
\hline 11 & 3.73 & 1.15 & 4.46 & 0.90 & 6.30 & 0.019* & 4.11 & 1.09 & 3.89 & 1.12 & 0.91 & 0.346 \\
\hline 12 & 4.42 & 0.90 & 4.62 & 0.75 & 0.63 & 0.434 & 4.25 & 1.00 & 4.28 & 1.09 & 0.01 & 0.905 \\
\hline 13 & 4.08 & 1.06 & 3.92 & 1.23 & 0.22 & 0.642 & 4.11 & 1.14 & 3.44 & 1.58 & 4.00 & $0.053 *$ \\
\hline 14 & 4.12 & 1.07 & 4.00 & 1.41 & 0.17 & 0.683 & 4.08 & 1.05 & 3.69 & 1.37 & 1.66 & 0.206 \\
\hline 15 & 3.69 & 1.09 & 4.15 & 1.08 & 2.29 & 0.143 & 4.14 & 1.05 & 3.86 & 1.05 & 1.70 & 0.201 \\
\hline 16 & 4.08 & 0.98 & 4.15 & 1.29 & 0.14 & 0.713 & 4.25 & 1.08 & 3.92 & 1.08 & 2.12 & 0.154 \\
\hline 17 & 3.69 & 1.32 & 4.27 & 1.15 & 3.59 & 0.070 & 3.58 & 1.32 & 3.83 & 1.18 & 0.93 & 0.342 \\
\hline Total & 65.31 & 9.51 & 71.31 & 14.58 & 5.71 & $0.025 *$ & 66.36 & 11.45 & 59.81 & 19.06 & 4.57 & $0.040 *$ \\
\hline
\end{tabular}

$\mathrm{M}=$ mean; $\mathrm{SD}=$ standard deviation

$* p \leq 0.05$.

experts in the classification of general EF, memory and attention functions. Some items that assess EF had lower agreement rates, probably because of the lack of consensus about EF theoretical constructs. ${ }^{36}$ The contributions made by experts to improve item comprehension were essential for the later understanding of the items by the patients. The content validity found in this study cannot be compared with those reported in previous studies of PCRS because they analyzed the full scale, which is composed of items about activities of daily living, interpersonal relationship, emotion and cognition. ${ }^{19}$ In addition, our items were taken from the four factors, and we found no other studies that have investigated specific processes involved in the activities described in the different items.

\section{Pilot study}

Our pilot study found data that are partially in agreement with some previous studies about the selfawareness of patients with TBI. Patients with moderate/ severe TBI had higher total scores than their relatives, demonstrating that they are less aware of their cognitive abilities than those close to them. ${ }^{37}$ Surprisingly, relatives of patients with mild TBI overestimated the patients cognitive abilities, as indicated by their total scores. A previous study reported similar results for PCRS items in a control group; according to those authors, the probable explanation for their finding was that individuals might have had the ability to mask their difficulties or hide them from relatives. ${ }^{38}$ This finding may reflect poor observation or the lack of opportunities to observe.

Further examination of the PCRS-R-BR items revealed that in the group of patients with mild TBI, items assessing financial abilities, episodic memory and ability to argue with others had the same pattern as the one described above. The analysis of items in the group of patients with moderate/severe TBI revealed the same pattern only in the item investigating the ability to remember people's names. These findings suggest that the relatives of the group of patients with mild TBI are more susceptible to overestimating patient abilities than those of the group of patients with moderate/severe TBI. At the same time, the answers given by patients with moderate/severe TBI indicated a lack of self-awareness in more items, according to the item discrepancy score. Some items in which the scores of relatives and patients with moderate/severe TBI differed significantly (items 1, 2, 7, and 13) were the same as the ones found in a study with a general sample of patients with TBI using the original PCRS. ${ }^{39}$ Abilities of planning, inhibition, semantic memory and theory of mind 
are expected to be impaired in terms of self-awareness. In addition, our findings support that severity is one of the main factors associated with self-awareness in TBI, ${ }^{40}$ as the groups with the most severe TBI are usually less aware of their cognitive impairments than those with milder conditions. ${ }^{38}$

\section{Final considerations}

The study draws attention to the importance of carefully adapting assessment instruments to cultural and linguistic variations. Several changes described in this study were essential for the application of the PCRS-R-BR to individuals in the Brazilian culture. Limitations of this study were the lack of a healthy control group, lack of further analysis and data collection to investigate other PCRS-R-BR validity criteria, and lack of studies to compare findings, as this was the first investigation to evaluate this tool. In addition, our scoring system with "not applicable" option may have influenced results; however this score option was infrequent and our findings are in agreement with previous literature, as previously cited. The adaptation of the PCRSR-BR should improve neuropsychological assessment using functional and ecological measures - one of the main concerns of contemporary neuropsychology. The present findings may also contribute to the establishment of functional diagnoses and rehabilitation plans for different clinical populations. In addition, the PCRS-R-BR may also be used as an outcome and follow-up measure, especially in rehabilitation settings. Future studies should investigate the correlations of PCRS-R-BR data with behavioral performance measures of $\mathrm{EF}$, attention, and memory, the effect of sociocultural variables on PCRS-R-BR results, and brain activity associated with self-awareness in different contexts.

\section{References}

1. Jurado MA, PuyedoR. Doing and reporting a neuropsychological assessment. Int J Clin Health Psychol. 2012;12:123-41.

2. Vakil E. Neuropsychological assessment: principles, rationale, and challenges. J Clin Exp Neuropsychol. 2012;34:135-50. 23. Almeida OP, Crocco EI. Percepção dos déficits cognitivos e alterações de comportamento em pacientes com doença de Alzheimer. Arq Neuropsiquiatr. 2000;58:292-9.

3. Burgess PW, Alderman N, Evans J, Emslie H, Wilson BA. The ecological validity of tests of executive function. J Int Neuropsychol Soc. $1998 ; 4: 547-58$

4. Sbordone RJ. Neuropsychological tests are poor at assessing the frontal lobes, executive functions, and neurobehavioral symptoms of traumatically brain-injured patients. Psychol Inj Law. 2013; 3:25-35.

5. Chaytor N, Schmitter-Edgecombe M, Burr R. Improving the ecological validity of executive functioning assessment. Arch Clin Neuropsychol. 2006;21:217-27.

6. Prigatano GP. Impaired self-awareness after moderately severe to severe traumatic brain injury. Acta Neurochir Suppl. 2005;93:39-42.

7. Prigatano GP. The study of anosognosia. USA: Oxford University Pres; 2010

8. Bivona U, Ciurli P, Barba C, Onder G, Azicnuda E, Silvestro D, et al. Executive function and metacognitive self-awareness after severe traumatic brain injury. J Int Neuropsychol Soc. 2008;14:862-8.
9. Ownsworth T, Fleming J, Desbois J, Strong J, Kuipers P. A metacognitive contextual intervention to enhance error awareness and functional outcome following traumatic brain injury: a singlecase experimental design. J Int Neuropsychol Soc. 2006;12:54-63.

10. Deaton AV. Denial in the aftermath of traumatic head injury: Its manifestations, measurement, and treatment. Rehabil Psychol. $1986 ; 31: 231-40$

11. Fleming JM, Strong J, Ashton R. Self-awareness of deficits in adults with traumatic brain injury: how best to measure? Brain Inj. 1996;10:1-15.

12. Bogod NM, Mateer CA, MacDonald SW. Self-awareness after traumatic brain injury: a comparison of measures and their relationship to executive functions. J Int Neuropsychol Soc. 2003;9:450-8.

13. Sherer M, Bergloff $P$, Boake $C$, High W Jr, Levin E. The Awareness Questionnaire: factor structure and internal consistency. Brain Inj. 1998;12:63-8.

14. Hart T, Seignourel PJ, Sherer M. A longitudinal study of awareness of deficit after moderate to severe traumatic brain injury. Neuropsychol Rehabil. 2009;19:161-76.

15. Prigatano GP. Neuropsychological rehabilitation after brain injury. Baltimore: Johns Hopkins University Press; 1986.

16. Smeets SM, Ponds RW, Verhey FR, van Heugten CM. Psychometric properties and feasibility of instruments used to assess awareness of deficits after acquired brain injury: a systematic review. J Head Trauma Rehabil. 2012;27:433-42.

17. Borgaro SR, Prigatano GP. Modification of the Patient Competency Rating Scale for use on an acute neurorehabilitation unit: the PCRS-NR. Brain Inj. 2003;17:847-53.

18. Barskova T, Wilz G. Psychosocial functioning after stroke: psychometric properties of the patient competency rating scale. Brain Inj. 2006;20:1431-7.

19. Hoofien D, Sharoni L. Measuring unawareness of deficits among patients with traumatic brain injury: reliability and validity of the Patient Competency Rating Scale-Hebrew version. Isr J Psychiatry Relat Sci. 2006:43:296-305.

20. Ramírez M, Ostrosky-Solis F. Datos normativos de la escala PCRS para la autoconsciencia en México y la influencia de la cultura. Rev Neuropsicol Neuropsiquiatr Neurocienc. 2008;8:21-33.

21. Ciurli P, Bivona U, Barba C, Onder G, Silvestro D, Azicnuda E, et al. Metacognitive unawareness correlates with executive function impairment after severe traumatic brain injury. J Int Neuropsycho Soc. $2010 ; 16: 360-8$

22. Schmitz TW, Rowley HA, Kawahara TN, Johnson SC. Neura correlates of self-evaluative accuracy after traumatic brain injury. Neuropsychologia. 2006:44:762-73.

23. Almeida OP, Crocco EI. Percepção dos déficits cognitivos e alterações de comportamento em pacientes com doença de Alzheimer. Arq Neuropsiquiatr. 2000;58:292-9.

24. Harkness JA, Schoua-Glusberg A. Questionnaires in translation ZUMA-Nachrichten Spezial. 1998. http://isites.harvard.edu/fs/ docs/icb.topic506406.files/znspez3 04_Harkness Glusberg.pdf.

25. Valentini NC, Villwock G, Vieira LF, Vieira JL, Barbosa ML. Validação brasileira da escala de autopercepção de harter para crianças. Psicol Reflex Crit. 2010;23:411-19.

26. Busch RM, McBride A, Curtiss G, Vanderploeg RD. The components of executive functioning in traumatic brain injury. J Clin Exp Neuropsychol. 2005;27:1022-32.

27. Vakil E. The effect of moderate to severe traumatic brain injury (TBI) on different aspects of memory: a selective review. J Clin Exp Neuropsychol. 2005;27:977-1021.

28. Mathias JL, Wheaton P. Changes in attention and informationprocessing speed following severe traumatic brain injury: a metaanalytic review. Neuropsychology. 2007;21:212-23.

29. Andrés AM, Marzo PF. Delta: a new measure of agreement between two raters. $\mathrm{Br}$ J Math Stat Psychol. 2004;57:1-19.

30. Iverson GL, Lange RT. Mild traumatic brain injury. In: Schoenberg MR, Scott JG, editors. The little black book of neuropsychology. Boston: Springer US; 2011.

31. Del-Ben CM, Vilela JA, Crippa JA, Hallaka JE, Labatec CM, Zuardia AW. Confiabilidade da " Entrevista Clínica Estruturada para o DSM-IV - Versão Clínica " traduzida para o português. Rev Bras Psiquiatr. 2001;23:7-10

32. First MB, Spitzer RL, Gibbon M, Williams JB. Structured Clinical Interview for DSM-IV-I. Washington: American Psychiatric Press; 1990.

33. Fonseca RP, Casarin FS, Oliveira CR, Gindri G, Ishigaki EC, Ortiz $\mathrm{KZ}$, et al. Adaptação de instrumentos neuropsicológicos verbais : um fluxograma de procedimentos para além da tradução. Interacao Psicol. 2011;15:59-69. 
34. Reichenheim ME, Moraes CL. Operationalizing the cross-cultural adaptation of epidemological measurement instruments. Rev Saude Publica. 2007;41: 665-73.

35. Gjersing L, Caplehorn JR, Clausen T. Cross-cultural adaptation of research instruments: language, setting, time and statistical considerations. BMC Med Res Methodol. 2010;10:13.

36. Miyake A, Friedman NP, Emerson MJ, Witzki AH, Howerter A Wager TD. The unity and diversity of executive functions and their contributions to complex "Frontal Lobe" tasks: a latent variable analysis. Cogn Psychol. 2000;41:49-100.

37. Prigatano GP, Borgaro $S$, Baker J, Wethe J. Awareness and distress after traumatic brain injury: a relative's perspective. J Head Trauma Rehabil. 2005;20:359-67.

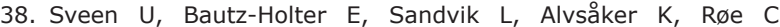
Relationship between competency in activities, injury severity, and post-concussion symptoms after traumatic brain injury. Scand J Occup Ther. 2010;17:225-32.
39. Leathem JM, Murphy LJ, Flett RA. Self- and informant-ratings on the patient competency rating scale in patients with traumatic brain injury. J Clin Exp Neuropsychol. 1998;20:694-705.

40. Morton N, Barker L. The contribution of injury severity, executive and implicit functions to awareness of deficits after traumatic brain injury (TBI). J Int Neuropsychol Soc. 2010;16:1089-98.

\section{Correspondence:}

Nicolle Zimmermann

Av. Ipiranga, 6681, prédio 11, 90 andar, sala 932

90619-900, Porto Alegre, RS, Brazil.

Tel./Fax: +55 (51) 3320.3500, ramal 7742

E-mail: nicolle.zimmermann@gmail.com 


\section{Appendix 1}

PATIENT COMPETENCY RATING SCALE - VERSÃO BRASILEIRA (PCRS-R-BR) - PARA PACIENTES

O questionário abaixo pede que você avalie a sua capacidade de fazer algumas coisas no dia a dia. As perguntas são relacionadas ao seu funcionamento após a lesão cerebral. Em cada pergunta, você deve julgar o quanto de dificuldade você tem para realizar uma atividade e apontar a resposta que explica melhor a sua opinião.

\begin{tabular}{|c|c|c|c|c|c|c|}
\hline Perguntas & $\begin{array}{l}\text { Não } \\
\text { consegue }\end{array}$ & $\begin{array}{l}\text { Muito } \\
\text { difícil }\end{array}$ & $\begin{array}{l}\text { Faz com alguma } \\
\text { dificuldade }\end{array}$ & $\begin{array}{l}\text { Razoavelmente } \\
\text { fácil }\end{array}$ & $\begin{array}{l}\text { Faz com } \\
\text { facilidade }\end{array}$ & $\begin{array}{l}\text { Não se } \\
\text { aplica }\end{array}$ \\
\hline \multicolumn{7}{|l|}{$\begin{array}{l}\text { 1) Quanta dificuldade você tem para preparar as suas } \\
\text { refeições? }\end{array}$} \\
\hline \multicolumn{7}{|l|}{$\begin{array}{l}\text { 2) Quanta dificuldade você tem em cuidar das suas } \\
\text { finanças? }\end{array}$} \\
\hline \multicolumn{7}{|l|}{$\begin{array}{l}\text { 3) Quanta dificuldade você tem em comparecer a } \\
\text { compromissos sem atrasos? }\end{array}$} \\
\hline \multicolumn{7}{|l|}{$\begin{array}{l}\text { 4) Quanta dificuldade você tem em iniciar conversas } \\
\text { em um grupo? }\end{array}$} \\
\hline \multicolumn{7}{|l|}{$\begin{array}{l}\text { 5) Quanta dificuldade você tem em se manter } \\
\text { envolvido(a) em atividades obrigatórias que tem que } \\
\text { terminar mesmo quando está se sentindo cansado(a) } \\
\text { ou entediado(a)? }\end{array}$} \\
\hline \multicolumn{7}{|l|}{$\begin{array}{l}\text { 6) Quanta dificuldade você tem para lembrar o que } \\
\text { você comeu no jantar ontem? }\end{array}$} \\
\hline \multicolumn{7}{|l|}{$\begin{array}{l}\text { 7) Quanta dificuldade você tem de lembrar o nome } \\
\text { das pessoas que você vê frequentemente? }\end{array}$} \\
\hline \multicolumn{7}{|l|}{$\begin{array}{l}\text { 8) Quanta dificuldade você tem em se lembrar dos } \\
\text { seus horários e compromissos do dia? }\end{array}$} \\
\hline \multicolumn{7}{|l|}{$\begin{array}{l}\text { 9) Quanta dificuldade você tem em pedir ajuda } \\
\text { quando está confuso(a) para resolver um problema ou } \\
\text { quando não entende alguma coisa? }\end{array}$} \\
\hline \multicolumn{7}{|l|}{$\begin{array}{l}\text { 10) Quanta dificuldade você tem em se ajustar a } \\
\text { mudanças que acontecem de uma hora para outra? } \\
\text { Por exemplo, você está se organizando para uma } \\
\text { atividade e de repente acontecem mudanças de } \\
\text { planos. Quanta dificuldade você tem em lidar com } \\
\text { isso? }\end{array}$} \\
\hline \multicolumn{7}{|l|}{$\begin{array}{l}\text { 11) Quanta dificuldade você tem em defender o seu } \\
\text { ponto de vista quando está conversando com as } \\
\text { pessoas? }\end{array}$} \\
\hline \multicolumn{7}{|l|}{$\begin{array}{l}\text { 12) Quanta dificuldade você tem em agir de modo } \\
\text { esperado quando está entre amigos? Por exemplo, } \\
\text { cuidando para não fazer coisas que as pessoas não } \\
\text { gostam. }\end{array}$} \\
\hline \multicolumn{7}{|l|}{$\begin{array}{l}\text { 13) Quanta dificuldade você tem em perceber que } \\
\text { algo que disse ou fez chateou outra pessoa? }\end{array}$} \\
\hline \multicolumn{7}{|l|}{$\begin{array}{l}\text { 14) Quanta dificuldade você tem em planejar as suas } \\
\text { atividades diárias? }\end{array}$} \\
\hline \multicolumn{7}{|l|}{$\begin{array}{l}\text { 15) Quanta dificuldade você tem em entender e } \\
\text { aprender novas tarefas? }\end{array}$} \\
\hline \multicolumn{7}{|l|}{$\begin{array}{l}\text { 16) Quanta dificuldade você tem em cumprir de } \\
\text { maneira efetiva as suas responsabilidades diárias? }\end{array}$} \\
\hline $\begin{array}{l}\text { 17) Quanta dificuldade você tem em se manter } \\
\text { concentrado(a) em uma atividade ou tarefa? Por } \\
\text { exemplo, quando quer ver um capítulo de novela até o } \\
\text { final ou assistir um programa de televisão até o final. }\end{array}$ & & & & & & \\
\hline
\end{tabular}




\section{Appendix 2}

PATIENT COMPETENCY RATING SCALE - VERSÃO BRASILEIRA (PCRS-R-BR) - PARA FAMILIARES

O questionário abaixo pede que você avalie a capacidade do seu(a) familiar, amigo(a) ou cliente de fazer algumas coisas no dia a dia. As perguntas são relacionadas ao funcionamento dele(a) no dia-dia ou após a lesão cerebral. Em cada pergunta, você deve julgar o quanto de dificuldade ele(a) tem para realizar uma atividade e marcar a resposta que explica melhor a sua opinião.

\begin{tabular}{|c|c|c|c|c|c|c|}
\hline Perguntas & $\begin{array}{l}\text { Não } \\
\text { consegue }\end{array}$ & $\begin{array}{l}\text { Muito } \\
\text { difícil }\end{array}$ & $\begin{array}{l}\text { Faz com alguma } \\
\text { dificuldade }\end{array}$ & $\begin{array}{l}\text { Razoavelmente } \\
\text { fácil }\end{array}$ & $\begin{array}{l}\text { Faz com } \\
\text { facilidade }\end{array}$ & $\begin{array}{l}\text { Não se } \\
\text { aplica }\end{array}$ \\
\hline \multicolumn{7}{|l|}{$\begin{array}{l}\text { 1) Quanta dificuldade ele(a) tem para preparar as } \\
\text { próprias refeições? }\end{array}$} \\
\hline \multicolumn{7}{|l|}{$\begin{array}{l}\text { 2) Quanta dificuldade ele(a) tem em cuidar das próprias } \\
\text { finanças? }\end{array}$} \\
\hline \multicolumn{7}{|l|}{$\begin{array}{l}\text { 3) Quanta dificuldade ele(a) tem em comparecer a } \\
\text { compromissos sem atrasos? }\end{array}$} \\
\hline \multicolumn{7}{|l|}{$\begin{array}{l}\text { 4) Quanta dificuldade ele(a) tem em iniciar conversas } \\
\text { em um grupo? }\end{array}$} \\
\hline \multicolumn{7}{|l|}{$\begin{array}{l}\text { 5) Quanta dificuldade ele(a) tem em se manter } \\
\text { envolvido(a) em atividades obrigatórias que tem que } \\
\text { terminar mesmo quando está se sentindo cansado(a) } \\
\text { ou entediado(a)? }\end{array}$} \\
\hline \multicolumn{7}{|l|}{$\begin{array}{l}\text { 6) Quanta dificuldade ele(a) tem para lembrar o que } \\
\text { ele(a) comeu no jantar ontem? }\end{array}$} \\
\hline \multicolumn{7}{|l|}{$\begin{array}{l}\text { 7) Quanta dificuldade ele(a) tem em lembrar o nome } \\
\text { das pessoas que ele(a) vê frequentemente? }\end{array}$} \\
\hline \multicolumn{7}{|l|}{$\begin{array}{l}\text { 8) Quanta dificuldade ele(a) tem em lembrar dos } \\
\text { horários e compromissos do dia? }\end{array}$} \\
\hline \multicolumn{7}{|l|}{$\begin{array}{l}\text { 9) Quanta dificuldade ele(a) tem em pedir ajuda quando } \\
\text { está confuso(a) para resolver um problema ou quando } \\
\text { não entende alguma coisa? }\end{array}$} \\
\hline \multicolumn{7}{|l|}{$\begin{array}{l}\text { 10) Quanta dificuldade ele (a) tem em ajustar-se a } \\
\text { mudanças que acontecem de uma hora para outra? Por } \\
\text { exemplo, ele(a) está se organizando para uma atividade } \\
\text { e de repente acontecem mudanças de planos. Quanta } \\
\text { dificuldade ele(a) tem em lidar com isso? }\end{array}$} \\
\hline \multicolumn{7}{|l|}{$\begin{array}{l}\text { 11) Quanta dificuldade ele(a) tem em defender um } \\
\text { ponto de vista quando está conversando com as } \\
\text { pessoas? }\end{array}$} \\
\hline \multicolumn{7}{|l|}{$\begin{array}{l}\text { 12) Quanta dificuldade ele(a) tem em agir de modo } \\
\text { esperado quando está entre amigos? Por exemplo, } \\
\text { cuidando para não fazer coisas que as pessoas não } \\
\text { gostam. }\end{array}$} \\
\hline \multicolumn{7}{|l|}{$\begin{array}{l}\text { 13) Quanta dificuldade ele(a) tem em perceber que algo } \\
\text { que disse ou fez chateou outra pessoa? }\end{array}$} \\
\hline \multicolumn{7}{|l|}{$\begin{array}{l}\text { 14) Quanta dificuldade ele(a) tem em planejar as } \\
\text { atividades diárias? }\end{array}$} \\
\hline \multicolumn{7}{|l|}{$\begin{array}{l}\text { 15) Quanta dificuldade ele(a) tem em entender e } \\
\text { aprender novas tarefas? }\end{array}$} \\
\hline \multicolumn{7}{|l|}{$\begin{array}{l}\text { 16) Quanta dificuldade ele(a) tem em cumprir de } \\
\text { maneira efetiva as responsabilidades diárias? }\end{array}$} \\
\hline $\begin{array}{l}\text { 17) Quanta dificuldade ele(a) tem em se manter } \\
\text { concentrado(a) em uma atividade ou tarefa? Por } \\
\text { exemplo, quando quer ver um capítulo de novela até o } \\
\text { final ou assistir um programa de televisão até o final. }\end{array}$ & & & & & & \\
\hline
\end{tabular}

